\title{
The Effect of Playing Science on Cognitive Development of Early Childhood at Melati Kindergarten in West Pasaman
}

\author{
Endang Citrowati
}

EarlyChildhood Department, Padang State University, Padang, Indonesia, endangcitrowati@gmail.com

\begin{abstract}
This study aims to determine the extent of the effect of playing science on early childhood cognitive development in kindergarten Melati, in Jorong Sakato Jaya, Sungai Aur, West Pasaman. This research method is pre-experimental design (nondesign) with pretest-posttest group design. This experimental subject is the children of Tk Melati, Jorong Sakato Jaya. Based on the analysis of the data shows that a significant effect on cognitive development. Thus, it is concluded that the science through play affects the cognitive development of children in kindergarten Melati in Jorong Sakato Jaya, Sungai Aur, West Pasaman, 2018
\end{abstract}

Keywords: Playing Science, Cognitive Development

\section{INTRODUCTION}

Early Childhood Education (ECD) is a form of education that focuses on the implementation of the foundation towards growth and physical development (fine and gross motor coordination), intelligence, creativity, emotional intelligence, multiple intelligence and spiritual intelligence. Growth and development of early childhood such as; growth and physical development, power think, creativity, social, emotional, language and communications must be balanced as the basis for the formation of a whole person.

It is also stated by (Yaswinda 2018) Early childhood education is the education provided from child birth to eight years old then also in line with the opinion (Suryana, 2016) early childhood education is to give guideline guidance to children from birth until six years old done by providing educational stimulus to help the development of children physically and mentally in order to have the readiness to enter further education.

Meanwhile, according to (Mulyasa, 2012) early childhood education, the most important base in the personal development of children, both with regard to the character, physical ability, cognitive, language, art, social, emotional, spiritual, self-discipline, self-concept, and selfreliance. Therefore, the provision of education to children stimuli we must first know how the characteristics of children and how children learn and play. Subsequently (Yaswinda, 2018) also said that early childhood is a time that is important to develop the ability of children, where the children will gain a variety of experiences.

Children develop continiously, which means that the level of development achieved in one stage expected to increase both quantitatively and qualitatively in the next development phase. Although every child is unique, because the child's development are different from each other are influenced by internal and external factors, but the child's development still follow a common pattern.

Early childhood is children aged 0-6 years. Children will learn something is not by sitting quietly, listening to testimonies from parents and teachers, but the child will learn something by playing. Early childhood is the golden age or often called the golden age of the mark with the rapid changes in the development of physical, cognitive, social, and emotional. In order for this period can be passed well by every child it is necessary to appropriate education for children at an early age

According to (Yaswinda, 2013) early childhood (AUD) has different characteristics from adults to behave. This is in line with the opinion (Suryana, 2013) Early childhood is a figure of the individual as a sociocultural beings who are experiencing developmental processes that are fundamental to the next life and have several characteristics. Early childhood is also called unique because children are organisms that represents the physical and spiritual unity of the whole.

Early childhood is the golden era in human development throughout the age range. This Golden Age occurred in the range of age 0-6 years. At this time, the growth and development of children in various aspects is undergoing rapid development. This is in line with the opinion (Sujiono, 2013) which suggests that childhood is the undergoing a process of rapid and fundamental developments for the next life.

According to (Rahmadani, A, 2019) Children who develop optimally is the children who were given the right stimulus. Development of human life in which the various aspects of children have experienced growth and development is very rapid.

In addition, Trianto also states that According to (trianto 2011) states that early childhood is a different 
individual, unique, and has its own characteristics according to the stage of his age. Early childhood (0-6 years) was the golden era (golden age) in which stimulation of all aspects of the development of an important role for the task of further developments.

In its activities while playing children will find new things that previously he did not know. In accordance with the characteristics of early childhood that are actively engaged in various activities to play, then the learning process is activity children in the form of learning while playing. Scientific process that can be done is with a scientific approach. The child process to obtain knowledge through the process of observing, ask, try, reason and communicate.

Eliason and Jenkins (2008) states that the development of cognitive, language, and literacy can shape thinking skills and build understanding. All aspects of the development of the above should get the maximum and optimal stimulation through learning activities that are meaningful to children involving parents, teachers and schools. Learning as it will have an impact on cognitive development, language development and literacy, physical-motor, social-emotional, as well as religious and moral values (Suryana, 2013; Purwati \& Japar, 2013).

According Yuliani Sujiono Conscience, et al (2005: $1: 12$ ), cognitive development is the development of the mind, the mind is the thinking part of the brain, the part used is for understanding, reasoning, knowledge and understanding. A child's mind is active since birth, from day to day throughout its growth. Development of the mind, such as; learn about the people, to learn something, learn new skills, gain a lot of memory, will add a lot of experience.

The benefits of playing in the cognitive aspects related to memory, comprehension, ability to understand the information, knowledge held by a person, reasoning power, power analysis, imagination and inventiveness or creativity (Reber, in Rini Hildayani, et al 2005: 4.7). Playing the game of science is an activity of the child to engage in exploration of various objects, both living things and inanimate objects around him. Kids learn to identify the symptoms and symptom events objects of these objects.

Through the process of science were trained to use the five senses of recognizing the kinds of objects symptoms and symptom events. Children are trained to see, feel, smell, taste and hear. The more senses involved in the study, children can increasingly understand what they learn. Kids gain new knowledge sense with various objects in the surroundings.

The knowledge will be useful as the important of thinking further. Through the process, the child can perform the simple experiment. The trial train children to connect cause and effect of a treatment which trains themto think logically.

Based on observations of the early researchers, teaching and learning in kindergarten Melati, Jorong Sakato Jaya, Sungai Aur, West Pasaman known that in the process of learning in the area of Science in grade B1dan $\mathrm{B} 2$, teachers are still using pictures and picture books in science learning, several times only in one month playing games or experimental science, because it is constrained by the tools and APE (games Educational tool) is not complete.

Playing science is a way that can be used in learning activities in kindergarten as well established as a teaching method. Learning to play to give opportunities for children to manipulate, repeating discover themselves, explore, practice and get an assortment of concepts and understanding are not limited to, such as playing color mixing science, sinking and floating objects and play science soluble and insoluble. From this limitation seems likely that when children play, children learn to take, choose, try, determine, express opinions solve problems and make decisions, that's when the learning occurs. Researchers interested in the third game of science is: play color mixing science, sinking and floating objects as well as playing science soluble and insoluble.

Based on the phenomenon that occurs in the field then the need for a change effort to do a teacher to help children in the development of cognitive abilities of children, one of them with a game of science. Playing science can help develop children's cognitive development. Can researchers conclude that science can be used to play as one of learning to develop the child's cognitive development?

\section{DISCUSSION}

Based on the problems studied then this type of research is quantitative method with experimental with pretest-posttest control group design. The population in this study is kindergarten Melati, Jorong Sakato Jaya, Sungai Aur, West Pasaman.

Based on the above concept, the population and the sample studied is the group B1 and B2. Where the group $\mathrm{B} 1$ used as the experimental class and group B2 used as a control class in consideration of the same child, learning the same, the background of the ability of the same teacher and recommendations from teachers both groups of kindergarten Jorong Sakato Jaya, Sungai Aur, West Pasaman.

The instrument used in this study is a test. The test is said to be valid if the test can measure what is to be measured. This instrument uses a Likert scale for assessment. Developing assessment criteria ie Very Good (BSB) were given a score of 4, Developing accordance Hope (BSH) were given a score of 3, Start Developing (MB) were given a score of 2, yet Evolving (BB) were given a score of 1 . According Arikunto (2010: 211) Validity is a measure that indicates the levels of validity or validity of an instrument. An invalid or valid instruments have high validity. Conversely, the less valid instrument means having a low validity.

Reliability test is a measure of the accuracy of a test when tested to the same object. Data analysis techniques used in this study was to compare the difference of the two average values, so it is done by $\mathrm{t}$ test (t-test). But before the first test of normality and homogeneity.

To analyze these differences, we need to test for normality. Syafril (2010: 211) states "Normality test used 
to determine whether the data to be processed is derived from the normal distribution of data. Normality test is done before processing the data by using product moment correlation, regression, t-test and ANOVA and so on. The technique is often used to test data normality is Liliefors test technique ".

Before the data is processed, in order to know a normal distribution of data or Liliefors then tested beforehand. One technique that is often used to test the homogeneity of the population variance is using Bartlett test. If you already know a normal distribution of data and new homogeneous data analysis according to the analysis technique that has been done. Is to find a comparison using t-test. Test data have been obtained with the formula t-test.

\section{RESULT AND DISCUSSION}

The pre-test cognitive development of children in the experimental class and control class average figures obtained experimental class is 68.75 , and the average number of control class 64.58. Based on the results of data analysis that tcount of 1.3807 compared with $\alpha$ of 0.05 $($ table $=2.04841)$ with degrees of freedom df $(\mathrm{N} 1-1)+$ $(\mathrm{N} 2-1)=28$. Thus $\mathrm{t}<\mathrm{t}$ table ie $1.3807<2.04841$, it can be said that the hypothesis $\mathrm{H} 1 \mathrm{H} 0$ is rejected or accepted.

Based on the above results there are no significant differences between early cognitive development of children in the experimental class and control class. Then based on the results of early cognitive development of children in the experimental class and control class in the post-test results obtained by the average number of experimental classes is 83.75 and the average rate of 76.66 Playing a fun activity

A Comparison of the results of the calculation of the value of the pre-test and post-test value can be seen in Table 1. Comparison Results Value Calculation Pre-test and post-test Value Early Childhood Cognitive Development

Table 1. Comparison Results Value Calculation Pre-test and post-test

\begin{tabular}{|l|c|c|c|c|}
\hline \multirow{2}{*}{ variables } & \multicolumn{2}{|c|}{ Pre-test } & \multicolumn{2}{c|}{ Post-test } \\
\cline { 2 - 5 } & Experiment & Control & $\begin{array}{l}\text { Experi } \\
\text { ment }\end{array}$ & Control \\
\hline $\begin{array}{l}\text { The } \\
\text { highest } \\
\text { score }\end{array}$ & 81.25 & 75 & 100 & 87.5 \\
\hline $\begin{array}{l}\text { The } \\
\text { lowest } \\
\text { value }\end{array}$ & 56.25 & 56.25 & 75 & 68.75 \\
\hline Average & 68.75 & 64.58 & 83.75 & 76.66 \\
\hline
\end{tabular}

\section{DISCUSSION}

The results of the post-test data analysis is done that tcount of 2.53214 compared with $\alpha$ of 0.05 (table $=$ $2.04841)$ with degrees of freedom df $(\mathrm{N} 1-1)+(\mathrm{N} 2-1)=$ 28. Thus $\mathrm{t}>\mathrm{t}$ table ie $2.53214>2.4841$ then it can be said that the hypothesis $\mathrm{H} 1 \mathrm{H} 0$ is accepted or rejected. It can be concluded that there is no influence of science play against cognitive development of children aged 5-6 years in kindergarten Melati, Jorong Sakato Jaya, Sungai Aur, West Pasaman.

Based on research that has researchers did look influences the pre-test and post-test. Pre-test results shows that the experimental class average is 68.75 and the average grade 64.58 control. Having seen the results of treatment given post-test children's early cognitive development in science class experiment with playing further increased by an average of 83.75 , while the control class using picture books earned an average of 76.66. It can be concluded that science plays an effect on the cognitive development of children aged 5-6 years in kindergarten Melati, Jorong Sakato Jaya, Sungai Aur, West Pasaman.

Based on the research results of cognitive development of children given the experimental class and control class at the stage of pre-test average figures obtained experimental class is 68.75 and the average rate of 64.58 in the control class. Based on the analysis that has been done that thitung 1.3807 compared with $0.05 \alpha$ (ttabel, = 2.04841) With degrees of freedom df (N1-1) + (N2-1) $=$ 28. Thus $\mathrm{t}<\mathrm{t}$ table, ie $1.3807<2.04841$, it can be said that the hypothesis $\mathrm{H} 1 \mathrm{H} 0$ is rejected or accepted. Thus, it can be concluded that there is no significant difference between the results of the cognitive development of children in the class with a science experiment with playing control class using picture books.

Each cognitive developments have an important role to the success of children in learning because most of the activity in learning is always associated with thinking problems. Theory of cognitive development of Jean Piaget in George S.Marrison (2012: 69), Explains how people think, understand and learn. Piaget believes that intelligence is "knowing" and involves the use of mental operations that develop as a result of physical actions in the neighborhood. Active involvement is the basis of Piaget's theory which states that children develop intelligence experiential / hands-on physical environment. This practical experience is the basis for the brain's ability to think and learn. Cognitive is a process of thinking, relate, assess, consider an incident or event.

Playing a fun activity of those involved in play activities. Because the cause of pleasure then the child will be easier to learn something. Play is an exciting thing. The game is designed in a creative and age-appropriate will provide valuable experience for many children.

According to Hurlock in Hendra Sofyan (2014: 56), defines the play is every activity carried pleasure, regardless of the final outcome. Play is voluntary and there is no coercion or pressure from outside. Science through play, children will learn a variety of knowledge and basic concepts. Knowledge of these concepts much more easily obtained through play activities, because the attention span of a toddler is still limited and anyway they are still difficult to manage, difficult to sit still for more than fifteen minutes. The best way and the most appropriate to introduce a range of knowledge and basic concepts of science is through play. For example, knowledge about the 
natural surroundings can be introduced through the plants, animals, insects that live in the child's environment.

While play science in the garden or in the field, they can reap knowledge about the environment. Thus, the children not only gain knowledge of the story the teacher in the classroom, or on the book he was reading, but through direct experience with seeing, watching, listening, holding, touching, and kissing direct these objects.

When researchers use play activities for development of cognitive science in the classroom (B1) kindergarten Melati, Jorong Sakato Jaya, West Pasaman, all children showed enthusiasm and passion in playing science. Control class using picture books for cognitive development. Kids seem less interested in playing with the teacher's picture books to learn, because children are getting bored with the monotony of learning, so children easily bored, because teachers use every picture book learning.

Based on the description it can be concluded that the results of cognitive development experimental class children better than the child's cognitive development in the control class. It can be seen from the average value of the experimental class children were higher than the control class. Thus, we can conclude that play sais can affect cognitive development in children.

\section{CONCLUSION}

Based on the analysis of research data has been stated above, it will be concluded some conclusions and suggestions to the research results. Results of research conducted in kindergarten Melati, Jorong Sakato Jaya, Sungai Aur, West Pasaman results child's cognitive development experimental class (B1) to play science higher than children in the control group (B2), which uses a picture book for developing cognitive development of (83.75) and the experimental group (76.66) control classes.

From the results of hypothesis testing results obtained $\mathrm{t}>\mathrm{t}$ table where 2.53214> 2.04841 as evidenced by the significant level $\alpha$ of 0.05 means that there are significant differences between the results of the cognitive development of children in the classroom science experiment by playing with the control class using picture books.

The researchers suggest addressed to Kindergarten Teacher Jasmine, Jorong Sakato Jaya, Sungai Aur, West Pasaman in order to play in the learning of science can be applied beyond. For Kindergarten Head Melati, Jorong Sakato Jaya, Sungai Aur, West Pasaman expected to be more motivating a more supportive learning in school to develop various aspects of child development, especially the development of the child cognitive. For further research that the results of this study can be a source of reading the literature for other researchers to develop research in the future.

According Mulyasa (2012: 16) Early childhood is the individual who is undergoing a process of growth and development is very rapid, even said to be a leap of development. Early childhood age range is very valuable than later ages because of the development of intelligence is extraordinary.

\section{REFERENCES}

[1] Arikunto, Suharsimi. 2010. Prosedur Penelitian Suatu Pendekatan Praktik. Jakarta: Rineka Cipta

[2] Hildayani, Rini, dkk. 2005. Psikologi perkembangan anak, Cetakan ke 2. Jakarta: Universitas terbuka

[3] Mulyasa. (2012). Manajemen PAUD. Bandung. Rosdakarya

[4] Morrison, George S. 2012. Dasar-Dasar Pendidikan Anak Usia Dini, Jakarta: Indeks

[5] Nurani, Yuliani,Sujiono,dkk. 2005. Metode Pengembangan Kognitif, Cetakan ke2. Jakarta: Universitas Terbuka

[6] Sofyan, Hendra. 2014. Perkembangan Anak Usia Dini dan Cara Praktis Peningkatannya, Jakarta : Infomedika

[7] Suryana, Dadan. 2017. Pembelajaran Tematik Terpadu Berbasis Pendekatan Saintifik Di Taman Kanak-Kanak. Jurnal Pendidikan Usia Dini. Volume 11 Edisi 1, April

[8] Suryana, Dadan. 2017. Pengetahuan Tentang Strategi Pembelajaran, Sikap dan Motivasi Guru. Jurnal Ilmu Pendidikan, Jilid 19, Nomor 2, Desember 2013, hlm. 196-201

[9] Suryana, Dadan .(2016) Stimulasi dan Aspek Perkembangan Anak. Jakata: Kencana

[10] Suryana, Dadan. (2013). Pendidikan Anak Usia Dini (teori dan praktik pembelajaran). Padang: UNPPress

[11] Syafril. 2010. Statistika. Padang: Sukabina Press

[12] Trianto. (2011). Desain Pengembangan Pembelajaran Tematik Bagi Anak Usia Dini TK/RA \& Anak kelas awal SD/MI. Jakarta: Kencana Prenada Media Group

[13] Yaswinda, Yulsyofriend \& Mayar. F. 2018. Pengembangan Bahan Pembelajaran Sains Berbasis Multisensori Ekologi Bagi Guru PAUD Kecamatan Tilatang Kamang Kabupaten Agam. Jurnal Pendidikan Anak usia Dini Yaa Bunayya

[14] Yulsyofriend, Yaswinda, Zulminiati. 2013. Pelaksanaan Model Reggio Emelio Pada Pembelajaran Anak Usia Dini di Taman Kanakkanak Asyofa Padang. Jurnal Ilmiah Ilmu Pendidikan

[15] Yaswinda, Mutie. Imam. 2019. Stimulasi Kesantunan Berbahasa Anak usia Dini di PAUD Hauriyah Halum, Padang

[16] Yaswinda \& Rahmadani, A. 2019. Pengaruh Permainan Outbound terhadap Perkembangan Sosial Anak di Taman Kanak-kanak Kemala Bhayangkari 03 Alai Padang. Jurnal Pprogram Studi PG 